\title{
From Landscape to Territory in Caribbean Canadian Literature: Repairing Caribbeanness and Denied Canadianness
}

\section{Rodolphe Solbiac}

\section{CpenEdition}

\section{Journals}

Electronic version

URL: https://journals.openedition.org/ces/4526

DOI: $10.4000 /$ ces. 4526

ISSN: 2534-6695

\section{Publisher}

SEPC (Société d'études des pays du Commonwealth)

\section{Printed version}

Date of publication: 1 September 2017

Number of pages: 135-146

ISSN: 2270-0633

\section{Electronic reference}

Rodolphe Solbiac, "From Landscape to Territory in Caribbean Canadian Literature: Repairing Caribbeanness and Denied Canadianness", Commonwealth Essays and Studies [Online], 40.1 | 2017, Online since 02 April 2021, connection on 25 January 2022. URL: http://journals.openedition.org/ces/ 4526 ; DOI: https://doi.org/10.4000/ces.4526

\section{(c) $(1) \&$}

Commonwealth Essays and Studies is licensed under a Licence Creative Commons Attribution - Pas d'Utilisation Commerciale - Pas de Modification 4.0 International. 


\section{From Landscape to Territory in Caribbean Canadian Literature: Repairing Caribbeanness and Denied Canadianness}

This paper analyses the decolonizing dimension of the reconnection of Caribbean and Caribbean-Canadian characters to Caribbean landscapes, their cultural affiliation to Canadian landscapes as well as their physical bonding to them in three Caribbean-Canadian novels of the new millennium. Grounded in Caribbean and Canadian ecocriticism, it argues that in these texts landscape writing serves to delineate the features of a Caribbean-Canadian identity in which Caribbeanness is repaired and Canadianness acknowledged and legitimized.

This essay aims at analyzing how Ramabai Espinet's The Swinging Bridge, David Chariandy's Soucouyant and Austin Clarke's More, all of which were published in the 2000 decade, imagine the Caribbean-Canadian relation to place. The three novels stage a turn in the way Caribbean-Canadian characters relate to the Caribbean and Canadian spaces, a change that takes them away from the feeling of placelessness previously found in these writers' works. Accordingly, this essay will seek to "throw into relief the symbolic operations through which literature makes sense of space" (Omhovère, Sensing 165). To this end, it will be focussing on landscape, as it constitutes one of "the symbolic transactions through which human communities turn indifferent space into a special place" (Omhovère, "Landscapes" 94). Finally, the approach to these novels through the prism of landscape representation is also justified by the fact that in postcolonial writing, landscape writing frequently appears "as a choice terrain of experimentation where to observe and inflect the formation of cultural memory" (Omhovère, "Memory" 286).

If "the fundamental role of Caribbean literature was to establish a dialectic between landscape and history and between culture and the natural world" (DeLoughrey 268), the development of Canada as a destination for Caribbean immigration and its subsequent emergence as a center of Caribbean literary production invite us to investigate the way in which Caribbean-Canadian novelists have imagined a new relation to place, considering that place is as much Canada as the Caribbean, and that the development of this new relation implies a metaphorical remapping (Ashcroft, Griffiths and Tiffin 31). Delineating this new relation to place requires that the characters' bond with landscapes should be explored since, according to W. J. T. Mitchell, landscape cannot be regarded as "an object to be seen or a text to be read, but as a process by which social and subjective identities are formed" (1).

This essay investigates how the characters of Espinet's, Chariandy's and Clarke's novels relate to both Caribbean and Canadian landscapes, in order to apprehend the social and subjective identities that are formed through them. It argues that these novels' fictional reprocessing of Caribbean landscapes and their representation of Caribbean-Canadian characters' relation to Canadian landscapes contribute to delineating the features of a Caribbean-Canadian territory, opening perspectives for the healing of a diasporic subject confronted with the throes of placelessness. Drawing on the approach of anthropologist Deborah Thomas in Exceptional Violence who chooses "reparations as a framework for thinking" (4) about contemporary problems, I will be arguing that these novels' collective enunciation is concerned with "the broader questions of how 
we [Caribbeans] make and remake ourselves in the contemporary world" (7). In the selected corpus, such an enunciation functions as a reparatory contribution to a Caribbean-Canadian historically informed sense of place sustaining a Caribbean-Canadian identity in which Caribbeanness is repaired and Canadianness acknowledged, claimed and legitimized.

This essay first examines the effect of the fictional reprocessing of Caribbean landscapes on the Caribbean-Canadian subject's vision of the past, before analyzing the interactions of Caribbean and Caribbean-Canadian characters with Canadian landscapes in their quest for home. It then explores the scope of these dynamic interactions with both Caribbean and Canadian landscapes in order to understand how they may redefine the diasporic Caribbean subject's territory and identity.

Apprehending the features and stakes of the Caribbean subject's relation to the Caribbean landscape is a necessary prerequisite for a study of the representation of Caribbean landscapes in The Swinging Bridge, Soucouyant and More. The Caribbean region has been greatly impacted by the European conquest and the plantation economy. Wilson Harris once commented upon this aspect, writing that the Caribbean "landscape [is] saturated by traumas of conquest" (8). In addition, for Caribbean people subjected to a colonial education, Caribbean landscapes hold the negative characteristics of secondrate places, a feature that Helen Tiffin analyses as follows:

With the institution of colonial education systems and other measures of formal education, the hegemonic power of English perceptions of land was vastly exacerbated. For colonized peoples an English landscape [...] became both normative and ideal, while the Caribbean was regarded as at best exotic, and at worst, aberrant or second-rate. (200)

However, "[w]hile the brutality of the plantation system produced a particular relationship to the natural world" (DeLoughrey, Gosson and Handley 2), in the wake of decolonization, many Caribbean writers sought to "re-establish a sense of place outside of the plantocracy by recuperating African and indigenous traditions maintained in Creole (or "folk") epistemologies, in rural or maritime communities, in the spaces of maroonage, and in the places where slaves and their descendants maintained their provision grounds" (DeLoughrey 266-7). Their literary action highlights the perception of individual interactions with landscapes, which Bill Ashcroft defines as follows:

[T] he ordinary social subject, when looking at the surrounding environment, does not simply take in what is there as purely visual data, but is located with that place in a cultural horizon, that is, the simply observed place is a cultural palimpsest built up over centuries and retaining the traces of previous engagements and inscriptions. (175)

Because Caribbean landscapes saturated by trauma have endured in the memories of Caribbean migrants to Canada, it is necessary to investigate the way in which CaribbeanCanadian novels deal with the relations embedded in the "cultural palimpsest" of landscape. The representation of Caribbean landscapes in The Swinging Bridge, Soucouyant and More has a revisionary function which instigates a new reading of place and makes possible a reconnection with the "time past" imprinted in space (Glissant 150). Combining the reprocessing of family memory and self-documentation, the characters inaugurate a relation with the Caribbean land that establishes it as a cultural horizon (Ashcroft 175).

Mona Singh, the protagonist of Espinet's The Swinging Bridge, has been living in Montreal for several decades when she is asked by her dying brother to return to Trinidad in order to buy back the family's land their father had sold before migrating to Canada. 
Her return to her native land turns into a quest for the landscapes that survived in her memories, and with which she confronts the geography she discovers as she travels through the country. The landscape of St Fernando holds the traumas of the IndoTrinidadian group. Endogamy, the rejection of Indian culture, essentialist re-affiliation to Indian culture, and fear of dilution characterize this Indo-Trinidadian community, which results in their non-participation in the national project:

The city of San Fernando housing its twin but separate populations, African and Indian, each lacerating the other, each tolerating the other's crossovers, the strayaways, the inveterate mixers seduced by curiosity and a taste for difference, whose blood and semen and juices would solidify and form the rickety bridge across which others might begin to cross the rapids that they feared would wash them out into the open sea. My place, this fertile, exuberant, wounded city. (103)

The almost imperceptible presence of female characters of Indian descent in the most rural part of Caroni alerts the reader to the condition of Indo-Trinidadian women subjugated to colonial and Indo-Trinidadian patriarchies. Mona's quest for her Indian ancestor leads her to discover a female tradition of resistance to patriarchy that redefines the identity of Indo-Trinidadian women. It also reveals the hidden riches of Indian culture, preserved as they are in the most despised parts of Caroni. In addition, the manifold affiliations of Indo-Trinidadian female characters to Amerindian, Indian and Afro-Trinidadian cultures that take place within the novel's scope suggest that this group can move away from non-participation. It is very significant that Mona, an IndoTrinidadian woman belonging to Montreal, and Bess, a woman of Afro-Indo-European ancestry from urban San Fernando, should both cooperate with more traditional IndoTrinidadian women from the most rural district in the country in their joint attempt at collecting remnants of Indian patrimony (282-3). Their involvement in the setting up of an Indian heritage museum, located in the Amerindian village of Iere, figures the construction of a shared sense of belonging to the land of a multicultural Trinidadian nation, endowed with a multidirectional memory. The narrator-protagonist refers to this new social and subjective Indo-Trinidadian female identity when she says: "I left Trinidad in the afternoon with a mixture of sadness and excitement. In a strange way, I felt as if I was leaving home for the first time" (304).

In Soucouyant, Carenage, a place close to Port of Spain, the largest city in Trinidad, is seen through the eyes of the second-generation Caribbean-Canadian protagonist seeking to reconnect with the legacy of his mother's Caribbean memory. The narrative combines his mother's memories with his own reminiscence of his unique childhood stay in Trinidad in its portraying of the slum and its destitute population. Because his mother was educated to abide by colonial standards, she views Carenage as a secondrate place:

This happened near Carenage, a village that extended from a seaside hill down to the blue. Carenage was an old village without a plan. It had winding lanes and abruptly ending roads and houses of different colours, each fashioned out of spare wood and corrugated metal from the ancient dockyards. [...] This wasn't a nice place, but one of waste and hard edges. A place where the city dumped its garbage [...]. (174)

What the protagonist learns about the village in the books provided by the librarian of Port Junction will, however, lead him to revise his opinion about the place (17495). His reconstruction of the social and historical memory of Carenage creates new 
positive associations that alter his initial assessment and prompt a fresh awareness of the economic importance of Trinidad for the British Empire. Carenage ceases to be a despicable slum in the protagonist's eyes when he realizes its importance as the place that once hosted the labour force necessary to keep up the war effort during WWI, as Miss Cameron reminds him: "Do you realize that in 1917, your mother's birthplace produced and refined a full three-quarters of the oil for the entire British Empire?" (106) This information entails a fresh perception of the landscape of Carenage which, as a result, becomes "invested with cultural agency" (Donnell 57). The Caribbean character can then connect to the "memory of the past time" he discovers through the palimpsest of histories and cultures found in Carenage: "There is a world of strange magic around Carenage. [...] Farther south there are villages celebrating Hosay and Diwali and Phagwa [...]. Farther south, again there is a pitch lake where the earth wells up black and prehistoric" (174).

In Carenage, African and Amerindian traditions have been kept alive in a folk culture that has also integrated Indian elements. Carenage reveals itself as a place of tradition and creolization combining the rural, the urban and the maritime. The meshing of African and Amerindian elements in Trinidad's cultural memory is represented in the mythological figure of the Soucouyant ${ }^{1}$ who is associated with pre-Columbian vegetation and the pharmacopoeia of local plants:

The old woman had long memories and the proper names for things. She knew the meaning of Chaguaramas itself. Named after the palms that used to line its beaches. Named by people who had been scattered by exploding weapons, by sicknesses that burst in pustules upon their skin. They were dispersed, these people, but their voice still haunted the place. Chaguaramas. The old woman knew the meanings of other names too. Carenage, for instance. [...] Most of all, the old woman could heal, a skill she had inherited from a long line of knowledgeable women. (181-2)

The novel More revolves around the memory of three decades in the life of Idora, a Barbadian woman who migrated to Toronto. From the basement where she spends a four-day retreat, the protagonist only catches the lights and noises from the outside. Her thoughts alternate between her native Barbados and the Toronto she discovered when she first arrived in Canada. The wayward narrative introduces the reader to the social conditions that compelled Idora to leave her native Barbados, at the same time as it explores the diverse facets of her early life in Toronto.

Representations of Barbados in More suggest that the island in the post-plantation period seemingly offered few if any opportunities to his inhabitants. In Idora's memories of her native land, post-independence Barbados was a place of fear and uncertainty holding no prospects for its youth. Her recollections of the fishing village in which her uncle lived - he had lost limbs in a shark attack - are dominated by the idea of fishermen trapped in the insular space. However, as Idora mentally revisits the Barbadian landscapes, she comes to acknowledge the fact that this place has nevertheless provided her with a culture from which she has derived the resources enabling her to cope with the challenges facing an immigrant in Canada. When Idora returns to her Canadian so-

1. "The Soucouyant is a creature of Caribbean folklore. It is a female, vampire-like creature that might disguise itself during the day as an old woman, but who, at night, sheds its skin and flies through the air as a ball of fire. The Soucouyant will then visit its sleeping victims to suck their blood; and the only indication that you might have in the morning that you have been visited by this creature is a bruise or discolouration on your skin." (Chariandy, The Fiction 112) 
cial life after her four days' retreat, she chooses the Barbadian language for her sermon in her religious congregation.

In all three novels, Caribbean landscapes are reconstructed and revised through a process that grants Caribbean-Canadian characters of both first and second generations an historically informed sense of place, liberating them from the colonial legacies of low self-esteem, the rejection of their native lands as places of limited importance and interest, places with no history and no future. These characters reconnect with the Caribbean landscape that, under their eyes, becomes a "cultural palimpsest built up over centuries and retaining the traces of previous engagements and inscriptions," which may provide them with agency (Ashcroft 175). These novels' revisions of Caribbean landscapes suppose a decolonization of the gaze allowing a new, emancipatory attitude to the place of origins. This ultimately contributes to a positive re-rooting of the Caribbean-Canadian diasporic subject in a rehabilitated Caribbean space. Such a process gestures towards a reparation of the negative legacy of colonialism.

In parallel with their attempts to reconnect with the Caribbean landscapes of their past, the same characters seek to establish close connections with Canadian landscapes in the process of finding a home in Canada. To understand the interplay between landscape writing and the development of a sense of home, it is necessary to say a few words about the role landscape has played historically in Canada.

Landscape has occupied a central place in the construction of a national identity in Canada. As Eva Machey explains, "[i]n nationalist mythology the nation is often represented as if embodied in the landscape itself" (125). Representations of the wilderness played an instrumental role in the formation of Canadian national identity. Representations of the Canadian wilderness, particularly in the Group of Seven iconography ${ }^{2}$ that became popular after WWI, have become inseparable from the feeling of belonging tainted with strangeness that defines the complex relation Canada's settler-invader culture has established with the natural environment. In fact, much more than a tangible natural entity, the wilderness is "also a perception, a concept and an inspiration. Or rather, it forms a complex of perceptions, concepts and inspirations" (Atkinson 228). Along with painting, literature in Canada has played a crucial role in fashioning ways of making space less alien, particularly through the elaboration of modes of representation, among which landscape features prominently, likely to help a nation of settlers and immigrants come to terms with the new land. Margaret Atwood once famously argued that a decisive function of literature was to provide Canadians with symbolic tools of orientation:

What a lost person needs is a map of the territory, with his own position marked on it so he can see where he is in relation to everything else. Literature is not only a mirror; it is also a map, a geography of the mind. Our literature is one such map, if we can learn to read it as our literature, as the product of who and where we have been. We need such a map desperately, we need to know about here [...]. (24)

In the first decades of the twenty-first century, the Caribbean immigrants portrayed in The Swinging Bridge, Soucouyant and More are still shown striving to establish a relation with

2. "If the Group of Seven had such on impact on a nation in search of itself after the blood sacrifice consented to the motherland in WWI, it is perhaps because these artists' manifesto of independence was immediately understood for its political implications: a turning away from European battlefields and a revision of the relevance of the local through a radical engagement with landscape." (Omhovère, "Landscapes in Transit" 108) 
their new home that will allow them to find a space in the nation. In fact, all three novels deal with the diasporic Caribbean-Canadian subject's desire to belong, and explore the question of finding a home in an unhomely Canada. The Caribbean-Canadian characters fear cultural dilution and resist Canadianness, but above all, they find it difficult to integrate a nation which, in spite of its alleged commitment to the national policy of multiculturalism, is still reluctant to embrace diversity. This is what Mona experiences in The Swinging Bridge:

When I arrived in the early seventies, Canada was a white country. If multiculturalism was an idea, it never touched me. For Da-Da, the moment of truth came when I saw a wall covered with graffiti that read Keep Canada White. As if it ever was. That first year winter piled up in huge drifts around me. I wrote in my journal that I had come to the edges of the First World and had been set adrift. (242-3)

Playing with the several associations of the adjective "white" - Canada's wintery landscape becoming an analogue for the whiteness of its social landscape - the narrator remembers her initial uneasiness in a space where she felt out of place, although she rebelled against this very idea: "I swore now that before another winter set in, I had to get myself back on course, but there was no course mapped out for me" (242-3). Taking its cue from Mona's resolution, this section will be exploring how the novels under scrutiny reconfigure the Caribbean-Canadian relation to space in an unhomely Canada. Analysing the textualisation of Caribbeans' response to Canadian landscapes will illuminate how these novels reconfigure Canadian spaces into landscapes, including the Caribbean-Canadian diasporic subject into a narrative that constructs his/her new subjective identity in Canada.

In The Swinging Bridge Mona's transformation into a Canadian takes a decisive step when she starts envisaging Canadian space as landscape, that is to say when she begins detecting beauty in the urban and natural environment and constructing meaning about herself in these spaces. In the first part of the novel she describes unhomeliness when she sadly recognizes that neither her family in Toronto nor she in Montreal have been able to establish a meaningful relation to Canadian space:

All of us migrants, the Chinese man, the Black waiter, Da-Da never finding a place here. [...] And Roddy, leaving the countryside of Scotland but finding a home here more readily than any of us, inventing a home, wanting so much to drag me into a home of his invention when I have invented none. Nothing. I have spent my life just getting by. (26)

Montreal is the place where she lives, loves, and creates, although she is unable to consider it home: "Montreal had provided me with a charmed space where I could live free of commitment. I was neither Québécoise nor Anglo; I had felt no passion about Quebec's future in Canada" (242). Yet, just like the protagonist of André Alexis' Childhood, Mona seeks to belong to Canada in spite of the "very unhomeliness" (Sugars 10) she feels around her. Owing to her professional accomplishments with Carene and her film company in Montreal (7), this country nevertheless appears as "a space which offers a potential for agency in the form of imaginative and cultural expression” (Sugars 10-1).

Mona's situation starts evolving when the protagonist begins to envisage the land of Ontario as a landscape on the train taking her to Toronto to visit her dying brother (26):

Muddie and Da-Da lived in a North Toronto suburb where all the houses were identical. In summer Muddie's gardening magic would transform their miniature front yard into a field of rhododendrons peonies $[. .$.$] and the line of ugly grey-toned warrens stretched$ 
into the distance. The stand of evergreens was splendid, though, pines and junipers shielding the windward side in a protective arc. (49)

The mother's gardening activity constitutes a patent example of what Alain Roger calls "artialisation in situ," as it consists of a direct intervention upon space (Roger 14). But Mona's perception of her parents' garden adds to this an artialisation in visu, evinced by her use of such words as "splendid," "shielding" and "protective." Mona's apprehension of Toronto changes when she begins seeing it as a landscape, a place where the beauty of the natural elements contrasts with the ugliness of the environment shaped by men. At this point Mona realizes that her parents live in a place where the natural landscape is protective, a place they have made their own through their gardening activity. Discovering that her parents now belong in Toronto raises the question of her own position. The protagonist feels torn between the city where her family lives and Montreal. However, being able to envisage Toronto as a landscape brings her quest for meaning to an end: "[s]omething had brought my drifting lifestyle to an end" (242). Becoming reconciled with the plurality of people's connections to place, Mona can come to terms with this tension and acknowledge her special bond with Montreal: "I am part of this city I live in, and right now I want no other place. Like any other migrant navigating new terrain, I bring my own beat to the land around me" (305).

Mona subsequently realizes that her family's belonging to Toronto, just like her belonging to Montreal, do not have to imply cultural amnesia. The novel foregrounds the process by which the identity of the diasporic Indo-Caribbean Canadian subject is constructed through the artialisation of Canadian space into landscape and the rewriting of the Trinidadian landscapes. With the new bonds they establish with Montreal, Toronto, San Fernando and Caroni, the characters come to realize that promoting Indian culture is not incompatible with their belonging to the Trinidadian nation, and belonging to the Trinidadian nation is not exclusive of their belonging to Canada.

In Soucouyant the protagonist's construction of Canada as a home territory partly results from the relationship he eventually succeeds in establishing with the landscapes of Scarborough. Chariandy's staging of the plight of second-generation CaribbeanCanadians in twenty-first-century Canada discloses the enduring dynamics of a country that began as a "white nation" (Agnew 321) and has long held its visible minorities as undesirables. ${ }^{3}$ The "nigger or Paki" (157) labels assigned to the protagonist by his White schoolmates identifies him as the target for Canadian xenophobia directed against both Afro-Canadians and Indo-Canadians. ${ }^{4}$

However, by having the protagonist's family reside in the mainly White suburban area of Port Junction, not far from Scarborough, Chariandy places Caribbeanness outside the specific dynamics of urban cosmopolitan Toronto, and makes it more visible. He also asserts the legitimacy of the presence of Caribbeans all over Canada, challen-

3. "Canada was constructed as a white nation through the nineteenth century, but from the mid-twentieth century the identity of Canada as nation and people came to be redefined by the presence, participation, and disputations of racialized citizens. [...] The documentation by racialized groups of their absence from histories, their silent omission from national stories, and their marginal presence in various discourses whether in the media or elsewhere have created a new and different realization of who 'we' are as a people and as Canadians." (Agnew 321)

4. "The dominant group treated Caribbean people who were of East Indian ethnicity much like they did those of African background. [...] The lashing out against this group occurred because Indo-Caribbeans and other people who were perceived as "East Indian looking" were seen as passive scapegoats for all the other 'Third World' immigrants arriving in Canada in the post-1967 period." (Plaza 218) 
ging the underlying conception of Canada as "a White nation" where it surreptitiously endures, in spite of the lip service paid to multiculturalism. ${ }^{5}$ If Soucouyant is mostly dedicated to the protagonist's re-rooting in Trinidad through his recapturing of his mother's memory, the affective bond he manages to establish with Scarborough is just as necessary as his fight against cultural amnesia. Under Miss Cameron's guidance, his readings encourage him to look differently at this part of Ontario and the position his own people have occupied in the region:

Miss Cameron had a passion for local history [...]. I learned about the Scarborough Bluffs and their geology. [...] I mostly learned about our community of Port Junction, which was established early in the 1800's. [...] Things had happened there. It wasn't just another suburb. It was a place with a past. (103)

The protagonist is surprised when, one day, he receives a book of poetry from Miss Cameron: "Years after, when I had broken all contact with Miss Cameron, when I had abandoned everyone of my past, and when I thought myself completely anonymous in the city, I received a brown package at my door" (106). The book contains a poem, "The Scarborough Settler's Lament," voicing the malaise of the first Anglo-Saxon immigrants who settled in the area. The poem makes him understand the importance of not neglecting the neighborhood of Port Junction (107). He then establishes the habit of taking his mother Adele and Meera, another second-generation Caribbean-Canadian, for walks on the beach of Port Junction, to develop a physical connection with the lake (109). The pleasure he feels as he strolls along the beach, admiring the lake and its clay bluffs, suggests that his growing sensitivity to the appeal of the landscape is dependent upon his embracing of the cultural memory of Ontario. Through this form of affiliation, the protagonist initiates a singular relationship with the very landscape that witnessed the inception of Anglo-Canadian society. "The Scarborough Settler's Lament," as a result, provides him with a literary map that gives him direction in a neighborhood which, subsequently, becomes his own territory.

In More, the protagonist's remembrance of her past life in Toronto is an occasion to record how her relation to Canadian space evolved over the past three decades. During her four-day retreat Idora reviews the years she has spent in Canada. She recollects how her immigration project took shape, the landmarks, pains, fears and disappointments that marked her life as a Caribbean immigrant in Toronto. As it discloses how living in Toronto altered Idora's Caribbean identity, the narrative takes the form of an introspective reconstruction of the character's relation to space through the inclusion of myriad memories - sounds and other physical sensations related to different urban places - for which Mickael Bucknor has coined the term "body-memory":

A poetics of memory, in my view, is one that attends to the way in which the body processes memory. [T] he body has the capacity to reorganize itself to accommodate alien matter. That process of re-composition involves unexpected interruptive re-call, disruptive codeswitching and repetitive retrieval. On each level of Clarke's narrative, linguistic and social coding, his aesthetic form exposes the re-compositional process of body-memory. (158-9)

5. "Decades after the inauguration of formal multiculturalism and the Charter of Rights, Statistics Canada continues to post a sociological reality revealing that current social practices make determinations based on skin colour alone. The legacy of Canada as a white settler society remains." (Hamilton 918) 
In More the artialisation of space is an internal process which occurs while Idora's wandering thoughts take her to different places in Toronto. As she remembers them, Idora names and describes these places in minute detail (1-17), including streets and districts in which Caribbean people live (11) and the famous Kensington market (8-9) patronized by immigrants from tropical countries. After several decades, she acknowledges her sensory responsiveness to the beauty of this town, in spite of the initial coldness that met her. Idora's reminiscences merge Caribbean, diasporic and Anglo-Canadian Torontonian spaces. The sounds that reach Idora in her basement stir memories of places, feelings, sensations that she experienced in this town. Idora's recovering of her aural memories in Toronto, including the music she heard over the three decades she spent there, fashions the aural features of this urban space, constructing it as soundscape through an acoustical experience of space. In this way, Idora reconnects with places like Massey Hall where such artists as Harry Belafonte, Sammy Davis Jr., and Miles Davis gave concerts she could not afford to attend. She would, however, listen to their tunes on the radio and, thus become connected to the cultural life of the city (294). Toronto's soundscape contributed to the formation of a North-American subjectivity for Idora, her personality evolving in response to the music she listened to in Toronto.

In a different yet complementary way, the bullet sounds that reach her in the basement also participate in the definition of the town as a dangerous, racist place. These sounds contribute to framing her identity as a black mother overwhelmed by the fear that her son may be killed by gangsters or by the police, like so many people of African descent in Toronto. From the sounds of the bells of the town churches, she also revisits the religious landscape of the city, in which she has a place as a pious Caribbean woman (142). As her thoughts wander between the two churches she attends, they introduce the reader to the social, economic and cultural divides that cut across Toronto. Idora hesitates between the Anglican Cathedral where she meets people, mainly from Rosedale and Cabbagetown - the rich Anglo-Canadian parts of Toronto - and a small apostolic church on the periphery of the city "where she could express herself as if it was at a dance, moving her body to the beat of rhythm and blues. [...] [There] in her community of West Indians, she was free" (80). When Idora attends mass in the Cathedral, she assumes that the congregation consists in rich people "who live in the condominiums on the four corners of the land surrounding the Cathedral" (78) and concludes that she is "the poorest in this congregation!" (78) Her hesitations between these two places of worship metaphorically represent her conflict in belonging and determine her as a West Indian immigrant experiencing placelessness. When the novel winds up after Idora's retreat has come to an end, her final liberation from this binary occurs when she comes to enjoy the bells of all the churches in Toronto chiming together as she strolls around:

She cannot get the tune the bells are playing. [...] This is not rock-and-roll. This is not rhythm and blues. But they make her soul light. And they bring back the joy of deliverance. And they seem to justify her affection for this city of Toronto, and for this country of Canada and for this community of Moss Park. (295)

In writing the landscape as a soundscape, the novelist observes the formation of Idora's Torontonian cultural memory through the lens that enhances the aesthetic appeal of Torontonian spaces.

The poetics of landscape in The Swinging Bridge, Soucouyant and More introduces us to the processes through which the reconfiguration of Canadian spaces into landscapes 
makes room for a territory where the Caribbean diasporic subject can develop a new subjective identity as Canadian. In these three novels, the re-envisioning of private memories leads to the reconstruction of a Caribbean historical memory, disclosing the wealth but also the economic or historical importance of despised, marginal or stigmatized places. Remembering Caribbean landscapes participates in a process of constructing a coherent and positive historical memory that provides the diasporic subject with a new, historically-informed sense of place. Granted with cultural agency, characters build on a rehabilitated historical memory to engage new relations with colonial, neo-colonial and post-colonial Caribbean landscapes as well as with Canadian ones. In the three narratives, the representations of Caribbean-Canadians' lives in Montreal, Toronto or other places in Canada inscribe a turn in their relation to Canada. Such a turn takes us beyond the lack of interaction expressed in Dionne Brand's volume of poetry Land to Light On which voices the impossibility for diasporic Caribbean subjects to affiliate, whether to Canadian or to Caribbean landscapes. This turn also expresses the emancipation of the Caribbean-Canadians from their position of perpetual newcomers. As George Elliot Clarke writes, the time of "the repression of Canada as a homeland" has passed (117).

The Swinging Bridge, Soucouyant and More propose original investigations of diasporic identities that produce "their own versions of cosmopolitan Canadian identity - versions which may be seen to strengthen commitment to social justice in Canada and even to love of the Canadian place" (Brydon 120). "Reconfiguring identity beyond the categories of the census and official cartographies" (ibid.), The Swinging Bridge, Soucouyant and More reroute the black Atlantic discourse of Gilroy and others to stress settlement and the putting down of new roots in Canada (Bristow et al), but always in such a way as to alter Canadian space and "the established discourse of the nation" (Brydon 120). Although becoming Canadian implies renouncing the prospect of a permanent return to the native land and becoming reconciled with the idea that they have now become Canadians, the characters reject cultural amnesia. On the contrary, their existence in Canada is based on a re-rooting in the Caribbean region revisited through memory. This revised Caribbean memory appears from then on as a constitutive element of a Caribbean-Canadian identity.

Like their twentieth-century predecessors, The Swinging Bridge, Soucouyant and More seek to establish a decolonized sense of place by recuperating African, indigenous, as well as East Indian traditions maintained in Caribbean landscapes. They concurrently seek to establish a sense of place by disclosing the unrecognized Canadian memory of Caribbean people living in Canada. The writing of landscape in these novels therefore discloses how Toronto, Montreal, and Port Junction become an integral part of the Caribbean imagination as home. In these novels, landscape writing is essential to the formation of the characters' cultural memory, liberating the Caribbean diasporic subject from the binaries that constrain belonging. In the corpus under scrutiny, landscape writing contributes to creating a multilocational sense of place in which home encompasses the Caribbean region as well as a wider Canada.

In their collective utterance, The Swinging Bridge, Soucouyant and More decolonize Caribbeanness through resistance to cultural amnesia. They establish Caribbeanness as a dimension of Canada, and include Canadian landscapes into their characters' sense of their own Caribbeanness. This utterance leads the Caribbean diasporic subjects to a reconciliation with their place of origin, empowering them to overcome their denied 
Canadianness, and bringing them closer to being emancipated from the posture of self-denied Canadianness. All three novels rehabilitate the territory from which their Caribbean diasporic characters originate and provide them with a new territory. Their authors therefore write towards the reparation of placelessness, pointing towards a future that will necessarily be Canadian. These novels appear as works written about as well as for social transformation. They call for a decolonization of representations of the Caribbean, just as they suggest the need to end the repression of Canada as a homeland. Finally, these works take us beyond a mere contribution to the decolonization of representations of the Caribbean subject. In fact, in their address of first- and second-generation Caribbean-Canadians' concerns, The Swinging Bridge, Soucouyant and More interrogate Anglo-Canadians and Canadians belonging to other minorities as well as Caribbean people living in the Caribbean region, presenting them with a new Canadian social subjectivity streaked with Caribbeanness.

Rodolphe SOLBIAC

University of the Antilles

\section{Works Cited}

Agnew, Vijay. Interrogating Race and Racism. Toronto: U of Toronto P, 2007.

Alexis, André. Childhood. New York: Henry Holt, 1998.

Ashcroft, Bill, Gareth Griffiths, and Helen Tiffin. "Cartography." Key Concepts in Post-Colonial Studies. New York: Routledge, 2001.

AтwоOD, Margaret. "From Survival: A Thematic Guide to Canadian Literature (1972)". Unhomely States: Theorizing English-Canadian Postcolonialism. Ed. Cynthia Sugars. Toronto: Broadview P, 2004. 20-28.

Brand, Dionne. A Map to the Door of No Return: Notes to Belonging. Toronto: Vintage Canada, 2002.

—. Land to Light On. Toronto: McClelland and Stewart, 1997.

Bristow, Peggy, Dionne Brand, Linda Carty, Afua P. Cooper, Sylvia Hamilton, Adrienne SHADD. "We're Rooted Here and They Can't Pull Us Up": Essays in African Canadian Women's History. Toronto: U of Toronto P, 1994.

Brydon, Diana. "Detour Canada: Rerouting the Black Atlantic, Reconfiguring the Postcolonial." Reconfigurations: Canadian Literatures and Postcolonial Identities / Littératures canadiennes et identités postcoloniales. Ed. Marc Maufort. Brussels: Peter Lang, 2002.109-120.

Bucknor, Michael. "Clarke's Poetics of (Body-)Memory in The Meeting Point." Austin Clarke: Essays on His Works. Ed. Camille A. Isaacs. Toronto: Guernica, 2013. 149-94.

ChARIANDy, David. Soucouyant, Vancouver, BC: Arsenal, 2007.

—. "The Fiction of Memory and the Language of Forgetting." Karuchuru 5.1 (2011): 109-14. < http:// repository.meijigakuin.ac.jp/dspace/bitstream/10723/821/1/culture5_109-114.pdf> (accessed 20 May 2017).

Clarke, Austin. More. Toronto: Thomas Allen Publishers, 2008.

Clarke, George Elliot. "Does (Afro-) Caribbean-Canadian Literature Exist? In the Caribbean?" Directions Home: Approaches to African-Canadian Literature. Ed. George Eliot Clarke. Toronto: U of Toronto P, 2012. 116-31.

DAsh, J. Michael. The Other America: Caribbean Literature in a New World Context. Vol. 4. Charlottesville: U of Virginia P, 1998.

Deloughrey, Elizabeth M., Renée K. Gosson, and George B. Handley, eds. Caribbean Literature and the Environment: Between Nature and Culture. Charlottesville: U of Virginia P, 2005.

Deloughrey, Elizabeth M. "Ecocriticism: the Politics of Place." The Routledge Companion to Anglophone Caribbean Literature. Ed. Michael A. Bucknor and Alison Donnell. New York: Routledge, 2011.

Donnelu, Alison. Twentieth-century Caribbean Literature: Critical Moments in Anglophone Literary History. London: Routledge, 2007.

Espinet, Ramabai. The Swinging Bridge. Toronto: Harper Collins, 2003.

Guissant, Edouard. Caribbean Discourse: Selected Essays. Trans. Michael Dash. Charlottesville: U of Virginia P, 1989. Trans. of Le Discours antillais. Paris: Gallimard, 1981. 
Hamilton, Roberta. "Cecil Foster, Blackness and Modernity: The Colour of Humanity and the Quest for Freedom.” Canadian Journal of Sociology 34.3 (2009): 916-20.

HARRIS, Wilson. The Whole Armour and the Secret Ladder. 1963. London: Faber \& Faber, 1973.

Mitchell, W. T. J. Landscape and Power. $2^{\text {nd }}$ edition. Chicago / London: U of Chicago P, 2002.

Omhovère, Claire. Sensing Space: The Poetics of Geography in Contemporary English-Canadian Writing. Brussels / Bern / Berlin: Peter Lang, 2007.

—. "The Memory of Landscape: Canadian Explorations on Site." Re/Membering Place. Ed. Catherine Delmas and André Dodeman. Bern: Peter Lang, 2013. 271-87.

- "Landscapes in Transit: The Displacement of the Western Landscape Tradition in English Canada." Authority and Displacement in the English-Speaking World - Exploring American Shores. Vol. 2. Ed. Florence Labaune-Demeule. Newcastle upon Tyne: Cambridge Scholars Publishing, 2015. 93-115.

PlazA, Dwaine. "The Construction of a Segmented Hybrid Identity among One-and-a-HalfGeneration and Second-Generation Indo-Caribbean and African Caribbean Canadians." Identity 6.3 (2006): 207-29.

Roger, Alain. Court traité du paysage. Paris: Gallimard, 1997.

Sugars, Cynthia. “'There's No Place Like Home’: The Unhomely Paradox of André Alexis' Childhood." Kunapipi 25.2 (2003): 7-23.

Thomas, Deborah A. Exceptional Violence: Embodied Citizenship in Transnational Jamaica. Durham, NC: Duke UP, 2011. 